\title{
Special Issue: After the Scientific Revolution: Thinking Globally about the Histories of the Modern Sciences
}

\author{
J.B. Shank \\ University of Minnesota \\ jbshank@umn.edu
}

\begin{abstract}
History of science today needs to fully escape from the categories and narrative frameworks created during the Cold War formation of the discipline. Most problematic is the portentous notion of science conceived as a uniquely European world-historical singular that founded modernity. The idea of a singular historical birth of science in the portentous singular, this article argues, is not a natural fact of world history, but a very recent conceptual invention that continues to do negative historiographical work. The idea of a history of modern science which takes as its starting point this imagined birth of singular science in the world-historical event called the "Scientific Revolution" is more problematic still. To move forward in a more globally conscious direction, our historiography needs to become comfortable rejecting this Cold War understanding of singular science, along with its origin story in the so-called Scientific Revolution of the early modern period. The result will be a new historiographical space where the global histories of the modern sciences in all of their diversity can be explored. In order to frame the contributions to this project offered in this volume, this introduction traces in outline the rise and fall of the classical early modern birth of singular science paradigm. It also suggests reasons why this framework has come apart in recent years and the new paths forward emerging out of its ruins.
\end{abstract}

\section{Keywords}

Science - the sciences - the Scientific Revolution - history of science - historiography the "Two Cultures" - modernity - early modernity - the disciplines - Europe - the West - world history - Eurocentrism - globalization 
Clio blinded me with Science!

Or there was no such thing as the "Scientific Revolution"

and it's just time to get over it.

How do we reckon with what Jorge Cañizares-Esguerra calls "the historiographical magic" conjured by narratives of the history of science? I italicize the last word because it is precisely out of this most enchanted of English words that much of the charm ensues. Are there any two words in modern English that are more marvelously bewitching than the couplet modern science? The sorcery is especially potent when the abracadabra is concentrated into the use of science, or even better Science, in the portentous singular. In this one incantatory utterance, supernatural powers, both bounteously beneficent and diabolically destructive, are awakened and sent into the world. To illustrate, consider a banal example of the potency of this everyday wizardry. MRI brain images, writes Martha J. Farah, are now "replacing Bohr's planetary atom as the symbol of science." The brain scans in this statement are not icons of brain science in particular, or neurobiology more generally, or even of our scientific mastery over the mind and consciousness. They are much more than that: symbols of modern science as a whole, singularly, universally, and tout court, or as I will call it science in the portentous singular.

Only in English is this singular and prophetic conception of science in all its bewitching power fully available. For only in English do we concentrate into one mesmerizing word our imagined human mastery over nature, or that capacity for Promethean knowing which many moderns take to be humankind's recent world-historical acquisition and the source of our cosmological dominion. This Anglophone discursive charm is also of very recent provenance. In the other European vernaculars, the older understanding of sciences in the plural (i.e. the natural or social sciences, not science by itself and singular) still remains common. Even when a singular notion of science exists in these European lexicons, as with wissenschaft in German or scienza in Italian, the singular serves merely as a composite suggesting a generic similarity among a

1 Martha J. Farah, "A Picture is Worth a Thousand Words," Journal of Cognitive Neuroscience 21, no. 4 (2009): 623-24. 
set of particulars. Singular science in this sense is not, as in English, a distinct thing with a wider portentous meaning and importance. In the same vein, the wissenschaftler, or practitioner of wissenschaft in German, can be everyone from a choral voice trainer and literary philologist to an atomic particle physicist. The pursuit of la ricerca scientifica in Italian likewise involves everything from archival historical inquiry and art historical theorization to experimental lab chemistry. Only in the Anglophone world (and really only in the United States, since England is more like Europe in this respect) are the sciences spoken of in relation to an imagined singular essence, science, which is claimed as the differentiating attribute that separates some sciences and scientific practices over and above all the others. Outside the West, the linguistic diversity is even more pronounced since no equivalent to singular science separate from authoritative knowledge in any particular domain (i.e. the sciences) can be found in any non-European language before 1900. That changed when the many complex and nuanced terms for the various and diverse world sciences started to be retrofitted to serve as local substitutes for (or negative contrasts with) this new Eurocentric Anglophone import.

The Ngram results below show clearly the very recent origin of this transformative linguistic turn. (Fig. 1)

Until roughly 1750, science and sciences existed side by side in English as singular and plural words describing reliable and authoritative knowing. By 1800, however, a gap had started to emerge, one accentuated and intensified over the next hundred years. By 19oo, singular science had come to stand to speakers of English for a singular Western way of knowing superior to all others, and this remains the situation today.

It was this emerging understanding of science in the portentous singular that led William Whewell to his feeling that a new word was needed to describe those who practiced science in this special yet universally superior way. Only in 1834-less than a hundred and seventy five years ago! — did Whewell coin the English word "scientist" to describe the makers of this new universal knowledge. "We need very much a name to describe a cultivator of science in general," he wrote in his Philosophy of the Inductive Sciences of $1840 .{ }^{3}$ Whewell's book offered an account of the general science that he claimed could be sifted from the particular sciences and made into a singular transcendent way of learning and knowing. Whewell also offered an accompanying and equally pioneering history of science that told of humankind's advance out of primitive

2 “scientist, n." oed Online. Oxford University Press. (http://www.oed.com/view/Entry/172698 ?redirectedFrom=scientist\&, accessed December 2016).

3 William Whewell, The Philosophy of the Inductive Sciences, 2 vols. (London, 1840), I: cxiii. 


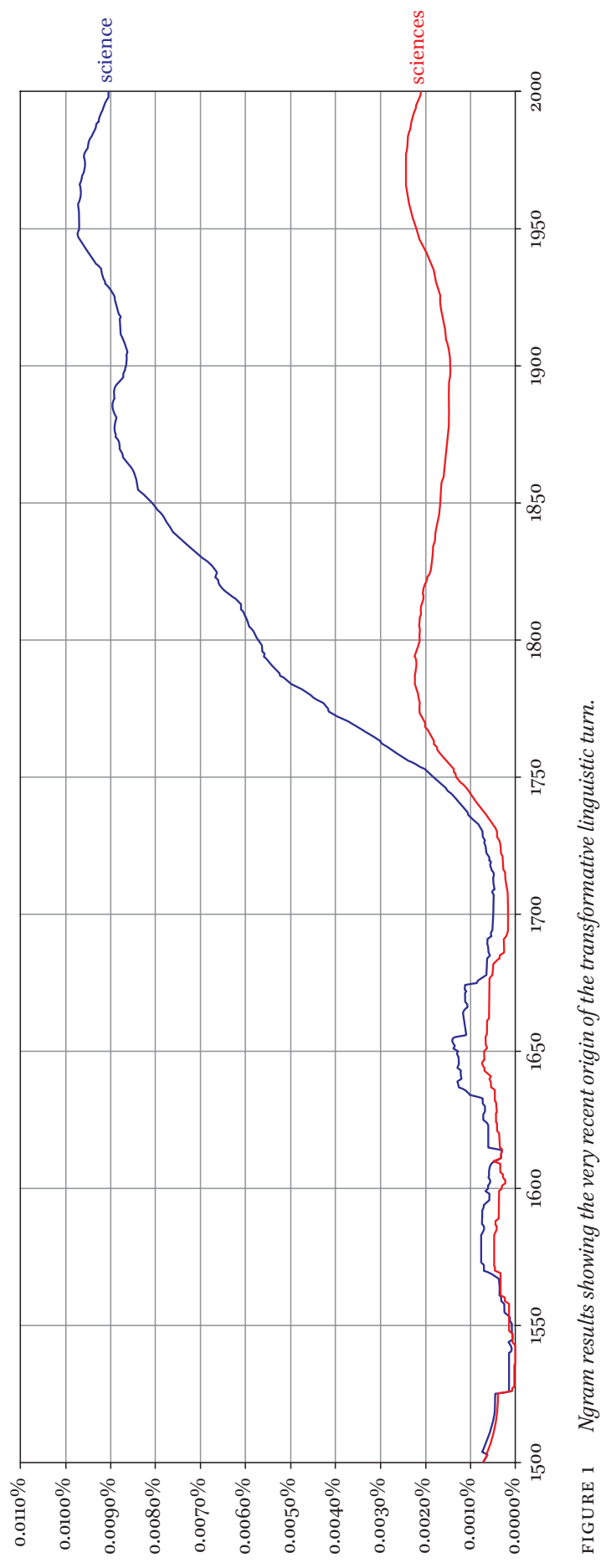


darkness and into the privileged light of universal scientific knowing and dominion.

After 1850, Whewell's understanding of science in general along with its universal history became centerpieces of the modern European self-conception. Ernst Mach offered his The Science of Mechanics, first published in 1883, as a precise historical account of the developments in European mathematics and physics that he argued constituted the essential foundations of this history. This book helped to inaugurate a tradition whereby certain mathematician physicists - Galileo, Newton, Faraday to name the luminaries - were claimed as the founding fathers of the new and modern science. ${ }^{4}$ Mach conceived of science as an empirical enterprise to be studied positivistically, but the Kantian rationalist Ernst Cassirer told a similar story with a similar pantheon of heroes in his 1906 Das erkenntnisproblem in der philosophie und wissenschaft der neueren zeit. ${ }^{5}$ Together they made the history of science a story of rupture, with forward looking moderns launching the new and world making enterprise through a break with the backward and unenlightened conceptions of their predecessors.

While widely influential and consensus making, the new universal history of science that Whewell, Mach, and Cassirer pioneered was not unanimously accepted. The Catholic conservative Pierre Duhem, for example, found much to complain about in the canonization of the heretic Galileo as a founder of modern science. He also disliked the anti-Christian bias of the whole story, especially its relegation of the Middle Ages to a regressive unscientific Age of Faith. A contributor to the philosophical debates that by 1900 were turning science into a newly self-conscious pursuit, Duhem wrote his own history of science that erased the great Renaissance divide separating the first modern scientists from their supposedly "Medieval" ancestors. ${ }^{6}$ His book did not discard the idea of a modern moment where science in all its word-historical importance was born, however. It rather moved the start back in time where it could coexist with Saint Thomas and the great builders of the Gothic cathedrals. Accordingly, the twentieth century inherited from the nineteenth both a new conception of science in the portentous singular, and a new historical debate about the precise moment and heroes responsible for this monumental, world-historical creation.

4 Ernst Mach, Die Mechanik in ihrer Entwicklung: Historisch-Kritisch Dargestellt (Leipzig, 1883).

5 Ernst Cassirer, Das erkenntnisproblem in der philosophie und wissenschaft der neueren zeit (Berlin, 1906).

6 Pierre Duhem, Le système du monde: histoire des doctrines cosmologiques de Platon à Copernic (Paris, 1913). 
The historical frame deployed by all these authors, which posits a moment (or moments) of repudiating rupture that break with the thought of the past and in turn points toward a path of progressive advance that realizes and develops in steps modern science, was not original or innovative to these writers. Its core features can be found in many places and times around the world. The Ancient Greeks deployed a version of it in their claim for philosophia as a superseding knowledge overcoming traditional religion and myth. A version is also found among medieval European scholastics-Duhem's heroes - in their use of the Latin word modernus, which literally means "now," to mark out the superiority of Christian natural philosophy when compared with the learning of the Pagans. The European Renaissance also launched entire paradigms of philosophical storytelling rooted in notions of ancient ignorance and darkness overcome by innovative steps forward into a new and better light. Out of this ferment, the plotting of the European "Scientific Revolution" started to be assembled, and one finds many of the essential pieces already in place in such pioneering works as Thomas Sprat's History of the Royal Society of London of 1666, Bernard le Bovier de Fontenelle's Histoire de l'Académie Royale des Sciences, first conceived in 1699 and then published in the 1730s, and especially in Jean Le Rond D'Alembert's Discours Préliminaire de l'Encyclopédie of 1751. It was upon this foundation that Whewell, Mach, Cassirer, and Duhem subsequently built, and from this perspective the crystallization around 1930 in the mind of Alexandre Koyré and others of the idea of an early modern birth of modern science in a so-called "Scientific Revolution" was less a new historiographical invention than a distillation of centuries of Western philosophical storytelling.

The Ngram chart below shows both the radically innovative nature of the historiographical category "the Scientific Revolution"-nonexistent before 1900! — and its explosive growth since $1945 .^{7}$ (Fig. 2)

The emergence of this master event cum analytical category also marks the arrival of a new disciplinary formation, the History of Science, built by a new cadre of professional academics created by the late nineteenth-century professionalization of the university. The new academic historians of science brought new specialized tools of research and scholarship to bear on the old stories of science and its history. As a consequence, by 1930 a new literature had begun to emerge produced by academic men of this sort (and a few women as well). It sought to explain the history of modern science through a rigorous

7 The red line charts the appearance of "scientific revolution" lower case, and the green line "Scientific Revolution" as a capitalized singular. 


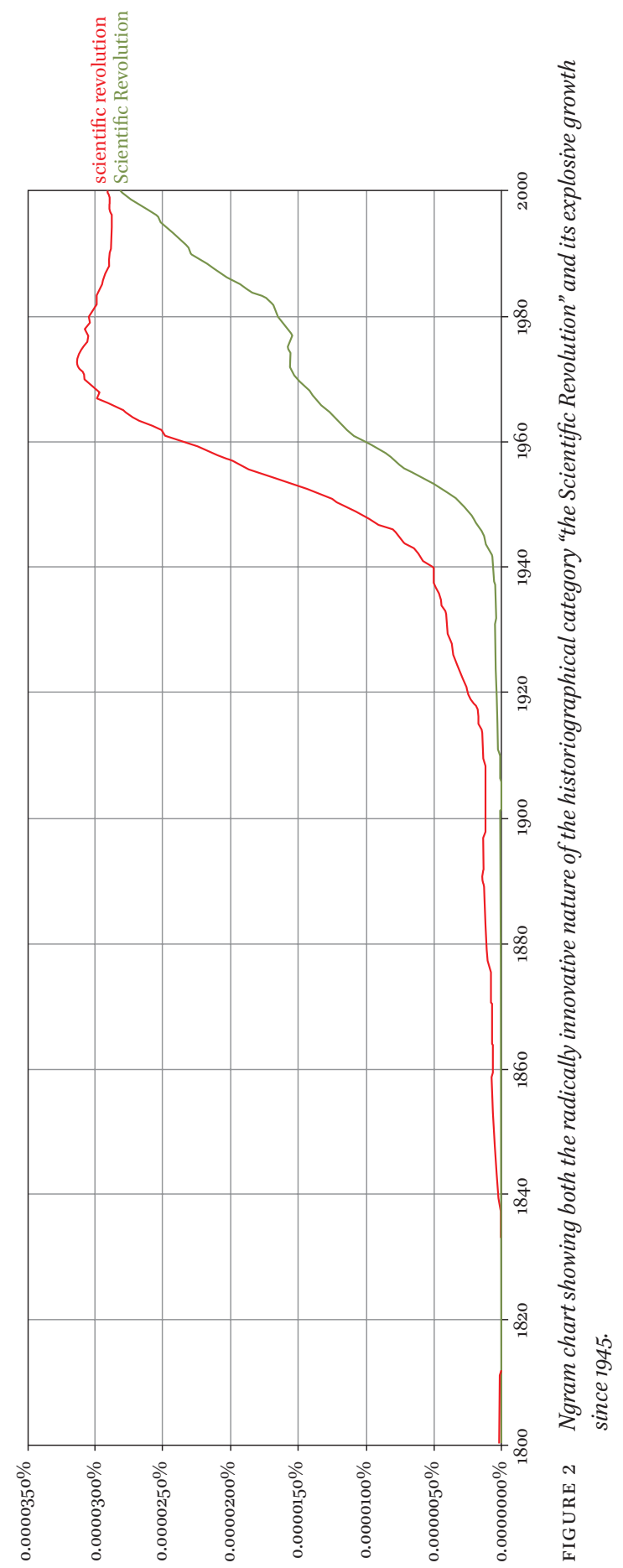

JOURNAL OF EARLY MODERN HISTORY 21 (2017) 377-393 frod from Brill.com04/26/2023 11:09:50AM 
historical account of its singular birth in and development after "the Scientific Revolution."

George Sarton is among the most famous of these early pioneers, and his escape from war ravaged Belgium to Cambridge, Massachusetts in 1915 made Harvard University an early hub of the new and emerging academic discipline of the History of Science. Sarton began teaching the new subject as early as 1910 , and he also began pioneering its scholarly literature. He projected a ninevolume work entitled A History of Science that would tell the story from earliest times to the present. He ultimately completed three volumes before his death in 1951, bringing the story as far as the fourteenth century. He also established at Harvard in 1924 the History of Science Society and its flagship journal Isis, which he actually began in Belgium in 1912. This society and its journal are still the institutional bedrock of the discipline today.

Similar urges toward the professional academic study of science also took hold in other locales at the same time. In Vienna, it coalesced around the so-called "Logical Positivist" circle and their journal Erkenntnis, founded by Rudolph Carnap and Hans Reichenbach in 1930. In Paris it came together in institutions like the Centre de Synthese and the Ecole Pratique des Hautes Etudes, where Koyré began teaching in 1922. In Rome, Aldo Mieli began to build an Italian home for the history of science through works like his own La storia della scienza in Italia published in 1926, and his journal Archeion. Archivo di storia della scienza founded in 1919. The last is still published today as Archives Internationales d'Histoire des Sciences.

The fascist unrest of the 1930s sent many of these European pioneers to the United States, further intensifying the international networks initiated by Sarton, Mieli and others. Out of this ferment emerged the Unity of Science Movement, which further crystallized the scholarly investigation of singular science. The University of Chicago, a home to many European academic expatriates, began to establish its distinguished place within the new disciplinethe University of Chicago Press has published Isis for the History of Science Society since 1991-by organizing a series of international Congresses on the Unity of Science and by announcing a publishing project, The Encyclopedia of Unified Science, which began to appear in 1938, although it was never fully realized. ${ }^{8}$ The first International Congress on the Unity of Science was held in Paris in September 1935, and subsequent annual meetings were held in Copenhagen (1936), Paris (1937), Cambridge, England (1938), and lastly at Harvard in 1939 .

8 Otto Neurath, Rudolf Carnap, and Charles W. Morris eds., Foundations of the Unity of Science: Toward an International Encyclopedia of Unified Science (Chicago, 1938). 
In 1933, Chemistry Professor James Bryant Conant became the twenty-sixth President of Harvard University, and from the outset he was a vigorous friend and champion of the new academic thinking about science. Drawing inspiration from Sarton's 1930 Colver Lectures, which were published the next year as The History of Science and the New Humanism, ${ }^{9}$ Sarton worked to make the history of science a centerpiece of his conception of university education in general by initiating in 1936 his "Program in the History of Science and Learning," arguably the first modern curricular program in the history of science. Thomas Kuhn developed his seminal idea of "paradigms" and "Scientific Revolutions" as a young lecturer in this program, eventually publishing his seminal work The Structure of Scientific Revolutions in 1961 as an unintentionally ironic contribution to Chicago's Unity of Science series. ${ }^{10}$

Among the first graduates of the Harvard program was also I. Bernard Cohen, who used Conant's curriculum to transform himself from a student of mathematics and physics into something new: a professional historian of science (Kuhn went on to become its academic twin: a professional philosopher of science). Cohen was awarded the second Ph.D. ever conferred in the History of Science in 1947, and soon after he took over the reigns of the History of Science Society and its journal Isis from his mentor George Sarton. He also revealed his debt to Conant and his program by publishing in 1948 a popular book entitled Science, Servant of Man. A Layman's Primer for the Age of Science. The book used a frontispiece image of Albrecht Dürer's Melencolia I and case studies in the history of science as a vehicle for showing war torn readers that a new dawn of human progress and improvement was arriving through modern science." Cohen eventually became a titanic figure in the new Cold War discipline of the History of Science, contributing especially through his work on Isaac Newton to the idea that modern science had been born all at once through the singular world-historical events of the "Scientific Revolution."12

Science, this new Euro-American academic scholarship began to assert confidently after 1950, was born all at once in a singular revolutionary upheaval triggered after $155^{\circ}$ by a small group of western European men. As the new

9 George Sarton, The History of Science and the New Humanism (New York, 1931).

10 Thomas Kuhn, The Structure of Scientific Revolutions (Chicago, 1961). The book was Volume II-2 of the "Foundations of the Unity of Science" monograph series.

11 I. Bernard Cohen, Science, Servant of Man. A Layman's Primer for the Age of Science (Boston, 1948).

12 See especially I. Bernard Cohen, The Birth of a New Physics, 2 ed. (New York, 1985, [1960]), and The Newtonian Revolution. With Illustrations of the Transformation of Scientific Ideas (Cambridge, 1980). 
academic field of the History of Science took shape, it planted its foundational footings upon this claim and began to build an academic discipline around it. It did so while also sustaining the wider claim that the "Scientific Revolution" was not just a historical event but a world-making transformation, one that opened planet Earth to a new modernity and the promise of a new and more progressive future. Conant, who retired from Harvard in 1953 to become the Secretary of State of the United States, also worked to articulate the larger importance of this new understanding in his books On Understanding Science, An Historical Approach published in 1947, Education in a Divided World, and The Growth of Experimental Sciences: An Experiment in General Education both published in $1949 \cdot{ }^{13}$ Cohen's Science, Servant of Man sent a similar message. In these widely-read tomes, these men of Harvard used the example of their university's innovative history of science curriculum to argue for the History of Science, and its core event "the Scientific Revolution," as a needed cornerstone for any modern liberal education program.

The fusion evident at Harvard by 1950 of the singular, portentous notion of science, with its academically certified birth certificate in the "Scientific Revolution," made this complex an intellectual gold standard for the times. From this base modern science became a new watchword for the age. Intensifying the new formation was the importance which science was seen to have played in the victories over the forces of fascism in Europe and Asia. Also crucial was its perceived importance in the new Cold War struggles with Communism, which were just beginning to erupt. Scientists by 1950 were widely held to have been important combatants in the war effort, and under the leadership of men like Conant, who served as a wartime manager organizing the sciences toward military service, the mobilization of science to fight the fascist enemies was widely held to have been a key reason for the Allies' triumph.

The label "The Physicist's War," which was being used to describe the conflict from as early as 1941, captures the popular understanding of this relationship, one rooted in the belief that specific sciences and technologies had proved decisive in the military victory. But in his epochal essay of July 1945, "As We May Think," Vannevar Bush offered a broader vision, one that praised the Western commitment to the liberal values of science in general as a core advantage in the struggle against the irrational violence and dehumanizing ideology of the fascists. ${ }^{14}$ Bush's call for massive new investments in the sciences in particular,

13 James Bryant Conant, On Understanding Science, An Historical Approach (New Haven, 1947); Education in a Divided World (Cambridge, MA, 1949); and The Growth of Experimental Sciences: An Experiment in General Education (Cambridge, MA, 1949).

14 Vannevar Bush, "As We May Think," The Atlantic (July 1945). 
along with the advance of science overall as a new organizing category for the national will, a call which the United States generously answered after 1950, was therefore of a dual nature. It was a direct and literal argument for more funding for university-based scientific research in the name of national defense, a proposal that was encouraged by the creation of the National Science Foundation in 1950, but also a broader call for a foundational commitment to promoting science in general as a moral bedrock for the nation. In short, it was Sarton's link between science and a new humanism retooled for the Post-War era.

In tandem with the growing and increasingly professionalized discipline of the history of science, with its new journals, academic meetings, doctoral programs, and research paradigms, the project of the history of science matured into a foundational Cold War enterprise, one with important cultural work to accomplish. Bush's appeal echoed Conant's arguments from the 1930s, which were newly published by $195^{\circ}$ and championed by Cohen in his role as leader of the History of Science Society and editor of its journal Isis. In this way the new discipline of the history of science acquired at its moment of creation and rapid professional maturation the two larger purposes that sustained it over the entire Cold War era.

Most important was its mandate to study the character and substance of science so as to insure its continuing prominence as a foundation for modern life. But just as important was its mission to illuminate within the heart of science a constellation of modern virtues that made it a form of rational ethics, which, when properly and rigorously pursued, allowed modern citizens to affix themselves to righteous principles and sift away the corrosive influences of irrational ideology. From this perspective, history of science as the story of the birth and growth of modern science offered a double benefit. It would help to promote the sciences themselves and to make better scientists (almost all of the new history of science programs created after $195^{\circ}$ came out of the natural science departments), and it would also provide, in the spirit of Sarton, Conant, Cohen, and Bush's vision for it, an intellectual and moral formation appropriate for rational liberal citizens in the modern age.

This particular political genesis of the new discipline and its core category of the "Scientific Revolution," shaped its precise character in decisive ways. One important outcome was the creation of a perceived distinction between history of science and history of technology, a division enshrined in the separate foundation of the Society for the History of Technology in 1958. Conant's vision of liberal education through history of science depended on a notion of science as a pure intellectual endeavor, one free from mechanical manipulation or knowledge as mere know-how. The emergence of an explicitly Soviet and Marxist history of science after 1945, most famously in the work of Boris 
Hessen, further pushed Western liberals toward an understanding of science as knowledge free from material or manual intervention.

The understanding of the "Scientific Revolution" constructed in this era was similarly oriented. The modern science born of this world-making seventeenth-century event, its first historians argued, was an entirely cerebral and theoretical affair devoid of any attachment to politics, society, material life, or even the bodies of the men that created it. Koyrés famous argument that Galileo was not really a mechanical experimentalist at all despite all appearances to the contrary, and someone who used hands-on demonstrations only to illustrate theories that he had already completely worked out in his head, was indicative of a whole body of literature that made the birth of modern science a purely mental development created by a new breed of free, rationalizing individuals. The new science in this literature was born ex nihilo in the disembodied minds of certain supernaturally rational men, and it flowed angel-like from their minds to the minds of others free of any political or social interest or muddying material mediation. The "Scientific Revolution" as narrated from this perspective was ultimately a completely idealist transformation, a result of freethinking men coming to mastery over nature through the pure work of their intellects alone.

Outside of this conception of the history of science stood history of technology on the one hand and the "externalist" material, social, and political history of the sciences on the other. It was out of this tripartite division that the Cold War discipline of the History of Science took shape. H. Floris Cohen has called the idealist narrative just described the "Great Tradition" of scholarship on the "Scientific Revolution," and the influence of this tradition cannot be overstated..$^{15}$ It is in fact still felt strongly today, as the recent attempts to reassert its value reveal. ${ }^{16}$

15 H. Floris Cohen, The Scientific Revolution: A Historiographical Inquiry (Chicago, 1994).

16 The recent works by Steven Weinberg, David Knight, William E. Burns, David Wooton, and H. Floris Cohen that exemplify this recent reassertion of the old narrative are surveyed nicely in John Henry, "The Scientific Revolution: Five Books About It," Isis 107, no. 4 (December 2016): 809-817. See also the discussion of these works by Babak Ashrafi, Lesley Cormack, William Eamon, and J. D. Fleming, and the response of H. Floris Cohen to the reviews of his work, in Metascience (June 2017). Also worthy of inclusion on this list, although not reviewed by Henry or discussed in Metascience, is Toby E. Huff, Intellectual Curiosity and the Scientific Revolution: A Global Perspective (Cambridge, 2011). For another call for returning to older narratives see, Nicholas Jardine, "World before word. Review of Lorraine Daston and Katherine Park eds., The Cambridge History of Modern Science. Volume Three: Early Modern Science (Cambridge, 2006)," Times Literary Supplement (14 September, 2007). 
This idealist paradigm of the "Scientific Revolution" also defined the relationship of science with other bodies of knowledge and other academic disciplines. Before World War II, Lynn Thorndike contributed to the newly emergent literature in the history of science by defining the history of magic and the occult as that body of knowledge that stood outside of, and thus defined through negation, the modern science studied by the new academic historians. ${ }^{17}$ This set the terms for the controversies triggered after the war by Frances Yates who argued that no firm lines should be drawn between early modern scientific and magical practices in the so-called birth of science after $1550 .{ }^{18}$ These same lines have since been blurred even further with respect to science and astrology, science and alchemy, and science and religion. Before 1980, however, these were not binaries to be scrutinized and dissolved, but firm boundaries that defined the coherence and autonomy of the unified discipline of History of Science. ${ }^{19}$ C. P. Snow performed similar boundary work in his 1959 Rede Lecture, which was subsequently published as The Two Cultures and the Scientific Revolution. ${ }^{20}$ In Snow's seminal formulation, science was an isolated domain set apart from the arts and humanities, and the challenge he issued was to find ways to drill tunnels of communication and understanding between these two seemingly isolated silos.

Such thinking was also instrumental in the idea that History of Science was its own separate discipline, one legitimately separate from others because it alone studied singular science. The conception of modern science as a singular European creation also led to the new geographical understanding of $s c i-$ ence that also became a dominant feature of Cold War global thinking. Joseph Needham's Science and Civilization in China, which began to appear in 1954, set up one paradigm by attempting to understand the apparent modern divergence of the West from rest in the presence (or not) of science within Chinese civilization. ${ }^{21}$ As Kapil Raj notes in this volume, Needham's "civilizational focus," which sought a global history of science through an analysis of the existence of this monumental singular within other "civilizations" ethnically or

17 Lynn Thorndike, History of Magic and the Experimental Sciences, 8 vols. (New York, 1923-58).

18 Frances Yates, Giordano Bruno and the Hermetic Tradition (Chicago, 1964).

19 As examples of the new trends, see the articles on "Alchemy," "Astrology," and "Magic" included in Lorraine Daston and Katherine Park, eds., The Cambridge History of Modern Science. Volume Three: Early Modern Science (Cambridge, 2006), and Paula Findlen's revised entry for the Jesuit "Athanasius Kircher" in the New and Revised Dictionary of Scientific Biography published in 2008.

20 C. P. Snow, The Two Cultures and the Scientific Revolution (Oxford, 1959).

21 Joseph Needham, Science and Civilization in China, 7 vols. (Cambridge, 1954-2015). 
historically defined, was one dominant Cold War approach to global history of science. ${ }^{22}$ Also influential was a diffusionist model that looked to chart the rise of global science by tracing its movements from its cradle in Western Europe to other places around the world. In each case, science was taken to be something singular and universal, a Western knowledge form different from and superior to the sciences found everywhere else. ${ }^{23}$

The "West" too was also solidified as its own portentous singular in these years through the reimagining of this place, which was at once potentially everywhere and nowhere in particular, as the home for singular science. In this way, many parts of the world were placed in relation to the West through evaluations of the presence or absence of science in them. This included Europe since many parts of it, such as the nations of the Iberian Peninsula and all the lands east of the Elbe, were excised from "the modern West" in this process because they were not places where the modernity making events of the "Scientific Revolution" were said to have occurred. In the case of Spain, this outcome was doubly ironic since this leader in European global expansion and empire was conceived to have been at the same time a fanatical Catholic enemy of modern "Western" science. This produced the quizzical image of a modern and European Spanish Empire conquering the world while at the same time being completely unmodern in a Western scientific sense.

Given the depth of the entanglement of science with Cold War society and culture more generally, it should have come as no surprise that the broader millennial culture wars that marked the passage from the Cold War era into today's twenty-first-century world order contained at their heart a set of widely visible and vitriolic "Science Wars." For as the clear binaries and moral truisms of the Cold War era began to disintegrate, the coherence and self-evidence of science came apart in tandem with them. A new kind of history of science was born in this context, one that challenged the understanding of science in the portentous singular, not because, as its critics claimed, these new historians were anti-science but because they could no longer take seriously the ideological claims that the twentieth century had sustained through this singular and highly normative piece of lexicographic magic.

This general cultural reorganization transformed the history of science, and especially the history of the "Scientific Revolution" that the "Great [Post-War]

22 Also illustrative of this approach is George Saliba, Islamic Science and the Making of the European Renaissance (Cambridge, MA, 2007).

23 An important critique of these approaches is found in Kapil Raj, Relocating Modern Science: Circulation and the Construction of Knowledge in South Asia and Europe, 1650-19oo (New York, 2007). 
Tradition" of scholarship had built from it. Instead of writing the history of the imagined birth and dissemination of this singular monolith, a new generation of historians after 1980 began taking singular science apart, exposing for scrutiny its many constituent elements, dynamics, and contests, and revealing for analysis the complex, contingent, and often discordant aspects of its history. The idea of science in the portentous singular works to efface such contingencies and historical nuances, and rather than perform this erasure, the new historians began to study the controversies at the heart of scientific practice, and to push on the tensions and fissures that have made the particular sciences what they are today and around the world.

When Steven Shapin infamously opened his 1996 book The Scientific Revolution by saying that there was no such thing as the "Scientific Revolution" and yet this was to be a book about it, he was using irony to reveal the state of the field that this millennial cultural reconfiguration produced..$^{24}$ On the one hand, for Shapin to say, as we have here, that there was no such thing as the "Scientific Revolution" is simply to announce what many in the field already feel: namely, that historians of science, like Francois Lyotard's postmoderns, are simply incredulous in the face of this old master narrative and the highly normative political and cultural projects that it reinforces. ${ }^{25}$ It is also to say as contemporary historians that we no longer see any value in writing history of science in the old way and want instead to develop new histories of the many and influential sciences that were once distilled into the magical historiography of the "Scientific Revolution."

In the book that Shapin nevertheless wrote about the non-existent entity in his title, he synthesized the best of the new histories of the early modern sciences that had started to emerge, and this is our other point of departure from Shapin's work. Despite its productive provocations, Shapin's The Scientific Revolution tells a fairly traditional story that mirrors the old Cold War narrative in many respects, not least in its northwestern European focus on developments in the mathematical physical sciences. It is no critique of Shapin to say that in the twenty years since his book was published, research into the topics, events, and developments that were not the "Scientific Revolution" but are nevertheless the topics of a book about it has grown even more diverse and complex. Were one to attempt a similar synthesis today, it would necessarily look very different than Shapin's, and by linking this volume with Shapin's call for an end to the "Scientific Revolution" framework, we are attempting to take his project to the next step by charting new paths forward toward a history of the modern

\footnotetext{
24 Steven Shapin, The Scientific Revolution (Chicago, 1996).

25 François Lyotard, La condition postmoderne: rapport sur le savoir (Paris, 1979).
} 
sciences, one that is not the history of science, but a diverse and complex set of histories of the many sciences that have worked to create the world that we live in today.

Especially important for us is the need to recognize the plurality of the sciences and their histories as a global phenomenon, and to write histories that make no unifying global claim and offer no moments of transcendent beginning or necessary, inevitable trajectories of change. The sciences in Europe remain central to this project, but when detached from their supposed role in the making of singular science they lose any special epistemological primacy or historical centrality, at least intellectually (their political history is very different). Given the pernicious Eurocentrism inscribed in the old notion of science and its imagined birth in northwestern Europe after 1550, we also propose a break from Europe altogether, or to effect a "Provincializing of Modern Science," to adopt Dipesh Chakrabarty's terms, so as to bring to light the many non-European histories that were erased by the old history of science and its claim of a singular birth of modern science during the European "Scientific Revolution."26

Included in this volume are six essays that each trace a new path forward with attention to different sciences, different geographies, and different historiographical agendas. Several come at the problem by trying to organize the sciences in relation to other historical dynamics. Harold Cook breaks with what he describes as the idealist and spiritual underpinnings of the "Great Tradition" scholarship by arguing for an insistence on the material, human dimension of scientific practice and a history of the sciences that is also and always a history of material objects in circulation within material relations of human commerce. Harun Küçuk follows a related path by giving a name to Cook's program, calling it "the new materialist historiography of science." He also complements Cook's economic and commercial understanding of the making of the sciences by bringing the state and global political relations into the analysis. Taking issue with the link made in the old "Scientific Revolution" literature between a singular northwestern European creation of science and the perceived Western initiation of global industrial development, Jorge Cañizares-Esguerra uses a comparative history of the pre-industrial technologies of Europe and the Americas to argue for a realignment of our understanding of global industrial history. Ahmed Ragab, focusing on medicine and medical institutions in the Islamicate Middle East, argues for a similar geographical reorientation by calling attention to the colonial structures that both

26 Dipesh Chakrabarty, Provincializing Europe: Postcolonial Thought and Historical Difference (Princeton, 2000). 
shaped medical science in the Middle East and continue to shape the histories we write about medicine in this part of the world. Kapil Raj continues in a similar vein, further reminding us of the way that colonialist understandings of "advanced civilization" and universal historical progress continue to infect our histories of the sciences and their global circulation. Carla Nappi adds still another approach, asking us to scrutinize the very foundations of our historical practice, and provoking us toward creative new methods of research and writing that may illuminate anew our understanding of the historical interaction of peoples, places, cultures, and knowledge.

By calling into question the old history of science and its founding event, the "Scientific Revolution," the essays in this volume are not attempting to part ways with the discipline that Sarton founded over a century ago. Most of us define ourselves as historians of science even if we also identify ourselves with other disciplinary identities and historical fields as well. We also struggle to integrate the histories of the sciences we find in our sources with a persistent history of science literature that still too often demands a demarcation between an imagined idea of modern science in the portentous singular and all the many kinds of authoritative knowing available across time and around the world. We resist that demarcation, and yet our mission is not to bury professional History of Science but to revive and reinvigorate it in meaningful and productive ways. Through this volume, we are seeking to join with the many other voices we encounter at Hss meetings and elsewhere in a program of realignment that aspires to draw the work of historians of science away from Cold War EuroAmerican notions of science and its imagined singular European birth in the "Scientific Revolution," and toward a new global understanding of the many sciences and their histories. Yes, we argue, the history of science has reached the end of its life and needs to be retired. But long live the history of science conceived as a study of the histories of the global sciences around the world and across time. 